far beyond any that might be expected, and they expose altogether the fallacy about the value of alcohol when with large quantities of water it has been administered as a supposed life-sustaining food.

\section{B. W. R.}

\section{WATERFOWL ${ }^{1}$}

$\mathrm{NE}$ of the principal objects of these lectures being the illustration of the animals exhibited in the Society's Gardens, I have selected for my address to you this day the subject of "Waterfowl," by which I mean the Anseres, or family Anatida, of naturalists, commonly known as ducks, geese, and swans. Three familiar species of domestic birds, the names of which I have just cited, belong to this family, and have been known to us since the times of the Romans, and a fourth, the Muscovy duck, has been added to the series since the discovery of America. Besides these four domestic species nearly all waterfowl show great aptitude for semi-domestication. When pinioned and put in small ponds, and supplied with food and shelter, most of them will thrive, and many of them will breed in captivity.

The acquisition of waterfowl has long been a subject of special interest to this Society. In 1830, in the first list of our animals ever published, I find thirty species of waterfowl included, amongst which are the Orinoco goose, Mandarin duck, and the Cercopsis goose. In I844 I find twenty-six species included in the catalogue of the animals then living in the Gardens. About that time the thirteenth Earl of Derby, then president of this Society, was the great patron of waterfowl, and, by means of collectors and agents in all parts of the world, brought together in his celebrated menagerie at Knowsley one of the finest collection of these birds ever made. At the disposal of the Knowsley menagerie by auction in $185 x$, examples of 51 different species of waterfowl were sold, many of which had been bred in the Knowsley Gardens.

Since that period the Zoological Society, having become the possessor of some of the choicest specimens sold at Knowsley, has taken up the subject of waterfowl with increased vigour, and has succeeded in adding considerably to the list of introduced species. During the past twenty years there have been exhibited in the Society's Gardens examples of 86 species of this group of birds, and at the present time the collection consists of not less than 270 individuals, referable to 53 different species, forming, as we believe, the finest living series of these birds now in existence. The zoological gardens of Amsterdam, Antwerp, and Berlin, and the Jardin d'Acclimatation of Paris have also excellent collections of waterfowl, and have succeeded in breeding some species which have obstinately refused to avail themselves of the inducements we have offered them in these Gardens. But in extent and variety I believe our series remains pre-eminent.

The total number of species of the family Anatidæ at present recognised by naturalists is about 175 ; of these some 94 , or more than half, have been at various times represented by specimens held in captivity either in our Gardens or elsewhere, and of the species thus exhibited no less than 50 have paired and produced young.

of the nine groups or sub-families into which, as will be seen by the Table, the Anatidæ are divisible, the Anatine or geese, swans, and river-ducks show the greatest aptitude for this kind of semi-domestication. The sea-ducks, lake-ducks, torrent-ducks, and mergansers are much more wild in their nature, and do not thrive nearly so well in confinement. Of the $3 \mathrm{I}$ known species of sea-ducks (Fuligulince) but I 3 are known to have been exhibited in zoological gardens, and of these only 5 have reproduced in captivity. None of the

I Abstract of a "Davis Lecture" given before the Z১ological Society of London, July 8, T880, by P. I. Sclater, F.R.S.. Secretary to the Society. lake-ducks (Erismaturina) or torrent-ducks (Merganet$\operatorname{tin} c$ ) have ever been introduced alive, and none of the Mergansers (Mergine) have been bred in captivity,

\begin{tabular}{|c|c|c|c|c|c|c|c|c|c|}
\hline \multirow[b]{3}{*}{ x. Anseranatinæ } & \multicolumn{5}{|c|}{ Table of Water-fowl } & \multicolumn{2}{|c|}{ Species } & \\
\hline & & \multicolumn{3}{|c|}{ Known. } & \multicolumn{3}{|c|}{ Exhibited. } & & Bred. \\
\hline & $\cdots$ & $\ldots$ & I & $\ldots$ & $\ldots$ & $\mathbf{I}$ & $\ldots$ & $\ldots$ & - \\
\hline 2. Cercopsinæ & $\ldots$ & $\ldots$ & $I$ & $\ldots$ & $\ldots$ & $\mathbf{I}$ & $\ldots$ & $\ldots$ & $\mathbf{r}$ \\
\hline 3. Anserinæ ... & ... & $\cdots$ & 38 & ... & $\ldots$ & 25 & $\ldots$ & $\cdots$ & I 4 \\
\hline 4. Cygninæ $\quad \ldots$ & $\cdots$ & $\ldots$ & Io & $\ldots$ & $\ldots$ & 8 & $\ldots$ & $\ldots$ & 5 \\
\hline 5. Anatinæ $\ldots$ & ... & ... & 75 & ... & $\cdots$ & 43 & $\cdots$ & $\cdots$ & 25 \\
\hline 6. Fuligulinæ ... & $\ldots$ & $\cdots$ & $3 \mathbf{I}$ & ... & $\ldots$ & I3 & ... & ... & 5 \\
\hline 7. Erismaturinæ & $\cdots$ & $\cdots$ & 9 & $\cdots$ & $\cdots$ & - & ... & $\cdots$ & - \\
\hline 8. Merganettinæ & $\cdots$ & $\ldots$ & 3 & $\ldots$ & $\ldots$ & - & $\ldots$ & $\cdots$ & - \\
\hline 9. Merginæ $\ldots$ & $\cdots$ & $\cdots$ & 6 & $\cdots$ & $\cdots$ & 3 & $\cdots$ & $\cdots$ & - \\
\hline & & & 74 & & & 94 & $\cdots$ & $\cdots$ & 50 \\
\hline
\end{tabular}

although examples of three species of the last-named group have been occasionally exhibited.

Of the geese (Anserina), on the other hand, which number some 38 known species, no less than 25 have been introduced at various times, and of these 14 have reproduced in captivity. Amongst these one of the best introductions effected by the Society is that of the Magellanic or upland goose, of which examples were first received in 1857, presented by Capt. Thomas Moore, at that time Governor of the Falkland Islands, in which settlement, as we know from no less an authority than that of $\mathbf{M r}$. Darwin, the upland goose is a familiar species. The upland goose commenced to breed with us in 1863 , and has continued to do so with tolerable regularity ever since; it has also hybridised in this country with the closely-allied form from Chili, which has been called Bernicla dispar, and of which many examples have been received by the Society in recent years.

Besides the upland goose, the allied ruddy-headed and ashy-headed geese of Antarctic America have been acquired and successfully bred. The ruddy-headed goose has unfortunately been lost, and requires reintroduction, but its ashy-headed brother remains a denizen both of these Gardens and also of similar establishments on the Continent.

Passing on to the swans, we find that a still greater degree of success has been obtained in the acclimatisation of these birds. Ten species of swans are recognised by naturalists, of which eight have been introduced into zoological gardens and five have been bred in captivity. Besides the common tame swan which is upon every piece of water, the ponds of our Gardens contain at the present time examples of the hooper, Bewick's swan, trumpeter swan, black swan, and black-necked swan, and but a short time ago we had also examples of the beautiful Coscoroba swan of Antarctic America, remarkable for its coral-red bill. Of all these the most engaging is perhaps the black-necked swan, originally obtained by the late Lord Derby from Chili, and first acquired by this Society at the dispersal of the Knowsley collection in $185 \mathrm{I}$. A pair of these tbirds first bred with us in 1857 , and the species has continued to do so with more or less regularity ever since that date.

The river-ducks (Anatina), which succeed the swans in the natural series, are the most numerous group of the family. Of the seventy-five known species of river ducks forty-three have been introduced into captivity, and twenty-five have been successfully bred. Of these I will call particular attention to two which have been recently added to the list of introduced species, and are charming representatives of the group.

The rosy-billed duck of South America was first introduced by this Society from Chili in 1867 , but only, unfortunately, in the shape of a single male. In 1870, however, we obtained examples of both sexes from the same locality, which began to breed with us in 1873 . Since then young ones have been batched nearly every 
year in the Society's Gardens, and we have been able to supply many of the gardens and collections on the Continent with pairs of this fine species.

Another successful introduction, from a very different quarter of the globe, has been the paradise duck of New Zealand. The so-called paradise duck belongs to the genus Tadorna, or shield-drake, and is remarkable, as I believe we werc first certainly able to ascertain from our living specimens, for the black head of the male being replaced by a brilliant white in the female. What is still more remarkable however is that in this bird the young in both sexes, contrary to what usually obtains amongst the whole class of birds, have the plumage of the male parent, the female birds putting on the white head only after the first moult. The paradise duck was first obtained by the Society in 1863 , when specimens of both sexes were presented to us by Mr. J. G. Tetley; the species first bred in the Gardens in May, 1865, and, assisted by the arrival of subsequent specimens, has continued to do so ever since, so that we have been able to supply many of our friends and correspondents on the Continent with examples of this duck, which may now be considered as firmly established in the gardens of Europe. Amongst other fresh-water ducks which have been successfully acclimatised in the same way within recent years I should also notice the Chiloe widgeon and the Chilian pintail, of Antarctic America, the spotted-billed duck of India, and the Brazilian teal, all of which have of late years bred freely in the Society's Gardens.

I will conclude with a few remarks upon the geographical distribution of the Anatidæ.

In treating of this part of the subject I find it impos-

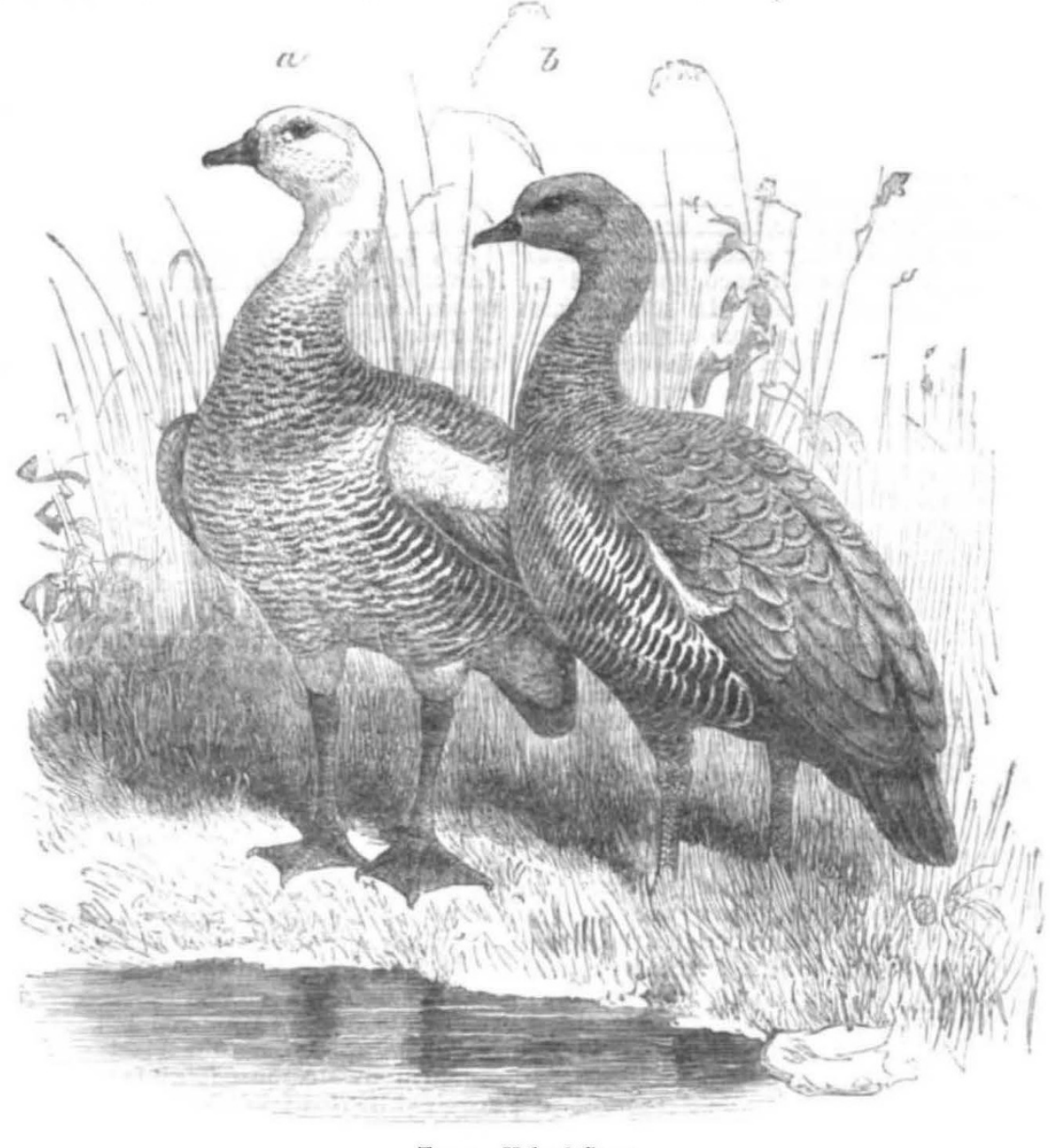

FIG. x,-Urland Goose.

sible to separate conveniently the Palæarctic and Nearctic species, or those of the northern parts of the Old and New World. So many of the high northern species are circumpolar or common to both continents, and so many other of the Palæarctic species have closely allied (in some cases barely separable) representatives in the Nearctic area, that it is much more natural to unite these categories into one group as "Arctic Anatidæ." Adding to this the other four generally recognised divisions, we shall find the Anatidæ come out, somewhat as follows, in five great geographical groups:-

I. ARCIIC ANATIDA.-The Arctic Anatidæe are by far the most numerous of all the five groups, these birds with their thick covering of feathers, and aquatic habits, being naturally adapted to cold and wintry climates. Out of the 38 known species of geese 20 , out of the ro known swans 7 , and of the 31 known sea-ducks not less than 26 belong to this category. Of the whole number of 174 gcnerally recognised species of Anatidæ, 77 may, I think, be best sct down as Arctic, although some of them, such as Tadorna rutila, Fuligula rufina, and Marmaronetta angustirostris, cannot be strictly so termed, as they inhabit only the temperate portions of the Palæarctic region. Very many of the Palæarctic species also, as will be noted below, go far south in winter and intrude far into the Ethiopian, Indian, and Neotropical regions.

II. ATHIOPIAN ANATIDe.-Under this head I place only those species that live all the year round, and breed within the Æthiopian region. These are about twenty- 
Amongst these are two generic forms not found else- $\mid$ two species only are peculiar to the island, Anas melieri where, Plectropterus and Thalassornis. Of the nine and $A$. bernieri, the remaining seven being also found in Anatidæ hitherto registered as met with in Madagascar |Africa.

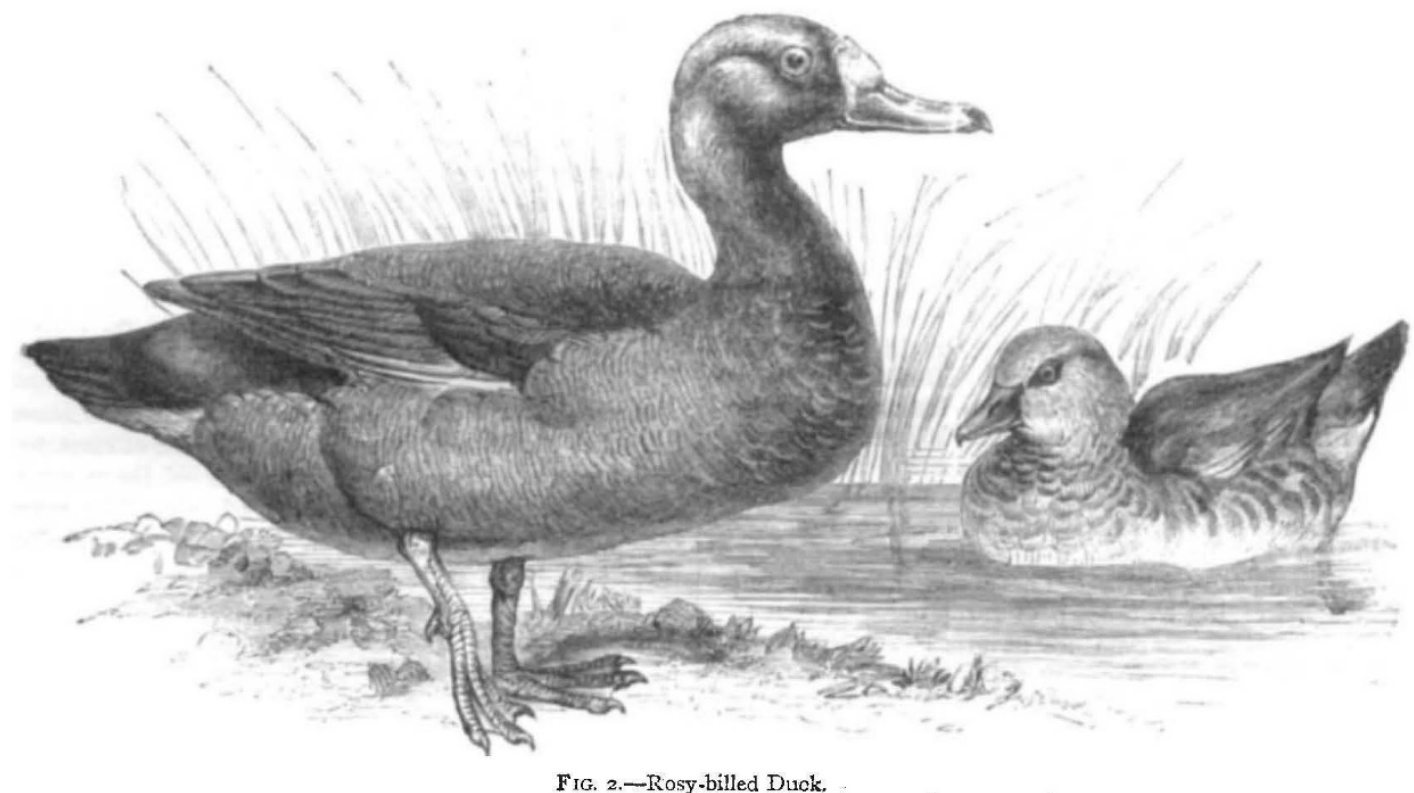

In winter, as will be seen by Heuglin's recent works, many of the Palearctic Anatidæ penetrate inte Eastern Africa.

III. INDIAN ANATIDE, - In this category again I include only species that are permanent inhabitants of some parts of the region. They are not numerous, consisting only of twelve species.

Amongst these there is only one peculiar generic form, Rhodonessa.

In winter, hawever, a host of immigrants from the north invade the Indian region. Jerdon gives us accounts of upwards of twenty northern dueks and geese which are found in various parts of the Indian peninsula in the cold weather.

IV.-Australian ANatrd E.-As we advance farther south the Anatidæ commence to increase again. Instead of only twelve native species we find the number in the Australian region running up to twenty-nine. The greater

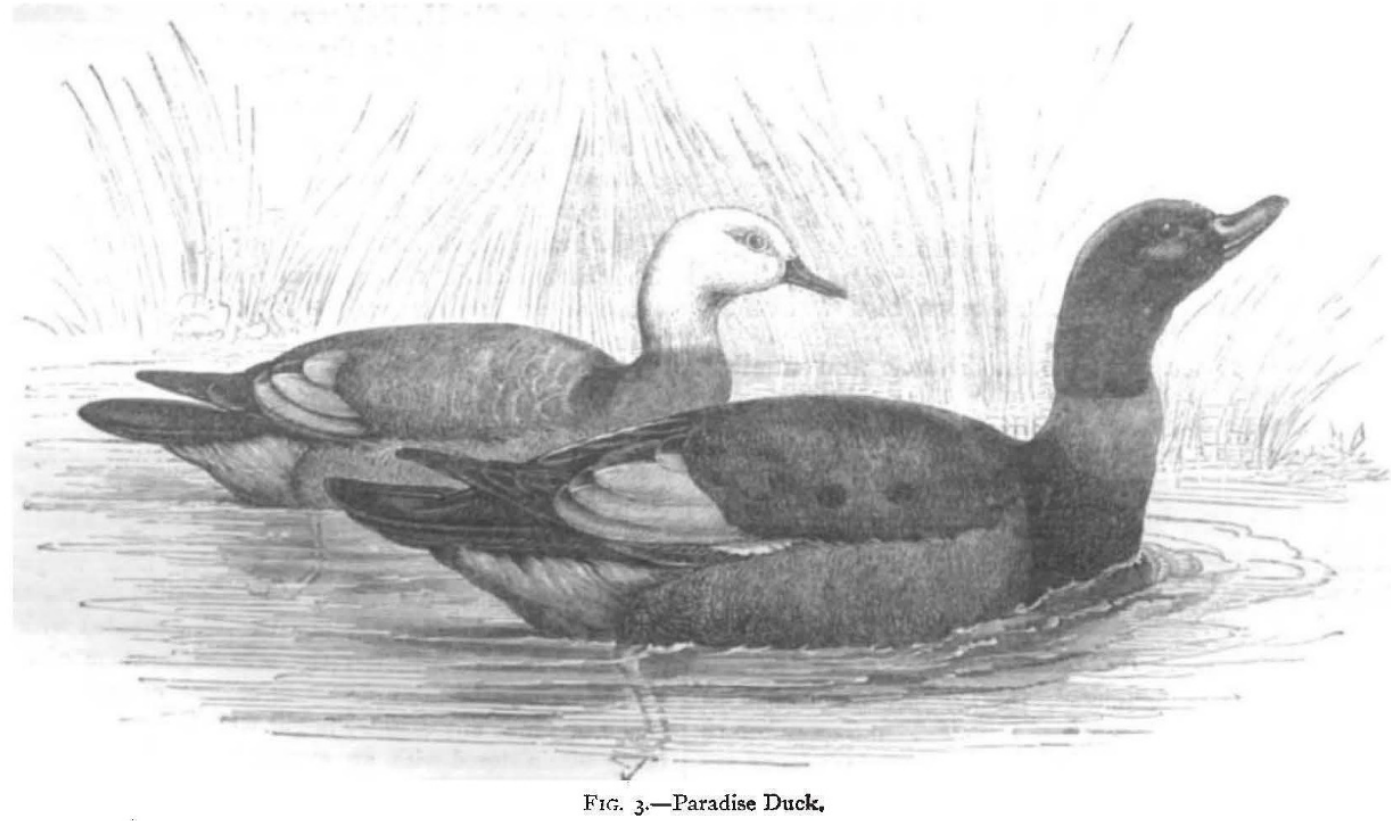

number of these are found in Australia itself, that great continent, although so dry and arid, being well supplied Among these there are no less than five generic monowith waterfowl. typic types peculiar to Australia, namely, Anseranas, Cereopsis, Stictonetta, Malacorhynchus, and Biziura. 
Proceeding to the outlying parts of the Australian region, we find New Zealand also well provided with Anatidæe, nine species being comprehended by Dr. Buller in his lately-published work on the birds of New Zealand, while the adjacent Auckland Islands are tenanted by two very peculiar ducks, quite unknown elsewhere, namely Nesonetta aucklandica and Mergus australis.

In Polynesia Anatidæ are scarce, Dendrocygna vagans and Anas superciliosa being the only species known until we come to the Fanning group, where the peculiar Chaulelasmus couesi has lately been discovered.

In the Sandwich Islands two peculiar species occur, Bernicla sandvicensis and Anas wyvilliana.

V. NeOtRopical ANATIDF.-The Neotropical region is better supplied with Anatidæ than any other of the divisions here adopted except the Arctic, thirty-nine species being specially attributable to it. Besides these, as Mr. Salvin and Thave shown in our articles on the Neotropical Anatidæ published in the Society's Proceedings for 1876, ${ }^{\mathrm{x}}$ twenty-three of the Arctic Anatidæ are more or less regular visitants to it during the winter season.

The generic types of Anatidæ restricted to the Neotropical area are four, namely, Heteronetta, Cairina, Tachyeres, and Merganetta. There are, however, only six species belonging to these peculiar genera, so that the mass of the Neotropical Anatidæ belong to Arctic forms.

On the whole the Neotropical Anatifauna (if such an expression be allowable) is not so peculiar, as that of Australia, where there are five generic types not found elsewhere. In true Anatida the Neotropical region is specially rich, possessing twenty-three species against the Arctic eighteen.

In Fuliguline, on the other hand, it is very poor, having only one species against the Arctic twenty-six.

In concluding my lecture I would venture to urge those who have friends and correspondents abroad; or who are so fortunate as to travel themselves, not to let any opportunity pass of adding to the Society's living collection of Waterfowl. In a paper recently read before the Zoological Society I have given a complete list of the known species of these beautiful birds, and an exact account of the introduction of each species that has been obtained alive, and if not, where it is to be found. I shall be happy to supply any one interested in the subject with a copy of this paper when in type, as it will shortly be. Meanwhile I may venture to specify some of our principal desiderata in different parts of the world.

I. Freshly-imported examples of the Cereopsis goose of Australia to cross with the present European stock.

2. Examples of the Bernicla cyanoptera of the highlands of Abyssinia, never yet obtained alive.

3. Examples of David's swan (Cygnus davidi) from Pekin. Even skins of this little known bird would be very desirable for our museums.

4. Specimens of the canvas-backed duck and smaller white swan (Cygnus americanus) of North America.

5. The pink-headed duck of India, of which we have only yet received a single pair in 1874 .

6. The Radjah shieldrake of Queensland (Tadorna radjah), a most beautiful species allied to our Tadorna vulpanser.

Any examples of these species would be most gratefully received by the Society for their living collection.

\section{NOTES}

As we have already intimated, the German Association of Naturalists and Physicians meets at Danzig from September 18 to 24. Contributions from non-German workers in science are earnestly asked for, and we are sure that any foreigners who desire to be present at the meeting will receive a hearty welcome. Applications for quarters should be made before September ro to Herr L. Biber, Brodbänkengasse 13, Danzig. Besides the

\footnotetext{
I Revision of the Neotropical Anatida, Proc. Zool. Soc., r876, p. 358.
}

usual excursions, concerts, and other social gatherings which the Germans know how to manage so well, there will be plenty of work in the twenty-three sections. Among the public lectures to be given are the following :-On September 8, "On Writing, Printing, and the Prevailing Shortsightedness," by Dr. Hermann Cohn of Breslau; "On some Characteristics of Cell-life," by Dr. Strasburger of Jena. September 2I-"The Food of Marine Animals," by Dr. Moebius of Kiel; "The Statics of Continents and the alleged decrease of the Water of the Ocean," by Dr. Jentzsch, of Königsberg; "The Scientific Standpoint of Psychiatry," by Dr. Wernecke of Berlin. September 24"Polar Expeditions or Polar Observatories," by Dr. Neumayer of Hamburg; "Foreign Domestic Birds, with special reference to the scientific results of their Breeding," by Dr. Carl Russ of Steglitz.

MUch capital is being made out of the reports of some of the inspectors in the new Education Report, "who attempt to enliven their pages by giving some of the results of the recent attempts at higher education in elementary schools. The answers are certainly ludicrous enough sometimes, almost as ludicrous as those said to be given occasionally by the undergraduates of Oxford and Cambridge. But the rational conclusion to be drawn from this state of things is not that which finds favour with Lord Norton and his friends, that the attempt to improve elementary education should be abandoned. As the Times well puts it:- "They are firstfruits : of the attempt to put to a higher and more exacting work instruments fashioned for a lower and a simpler one. All such results are at first necessarily imperfect, and nothing is easier than to make them appear ridiculous. The true remedy, however, is not to reject the instruments, but to adapt them, or give them the means of adapting themselves, to the higher function." If science is to be taught in elementary schools, let it be taught in a proper manner by properly trained men.

Evidentuy the Government of New Zealand have no fear of over-educating the people. From the Colonies we learn that the New Zealand system of education has been characterised by the Governor, Sir H. Robinson, as "the most ambitious yet adopted in any country in the world." To quote the words of Sir Hercules:- "It is proposed in New Zealand to provide the whole juvenile population with instruction free of charge in the following subjects:-Reading, writing, arithmetic, English grammar and composition, geography, history, elementary science, drawing, object lessons, vocal music, drill, and, in case of girls, needlework and the principles of domestic economy. The scheme includes also provision at the public expense for a system of scholarships, for the maintenance of normal schools for training teachers, for the efficient inspection of public schools, and for the erection of suitable school buildings. As soon as sufficient school accommodation has been provided the Education Act contemplates that attendance at public schools shall be made compulsory on all children between the ages of seven and thirteen who may not be otherwise under efficient or regular instruction." While Sir Hercules thinlss the programme may be too varied and too costly, he attaches little weight to the objection that there is a risk of over-educating the masses above their occupations and so making them discontented with their lot in life. While he criticises the scheme in some of its details, still he says :- "I think that your scheme of national edlucation is one of which any country might well feel proud, and that it is being administered with an earnestness and an ability which is deserving of all praise. I have been much struck, in travelling about the country, with the deep interest which is universally taken in this most important question, and with the determination which pervades the whole community that the blessings of education shall for the future be placed within the reach of all. 